Review

\title{
Review of Evidence of Environmental Impacts of Animal Research and Testing
}

\author{
Katherine Groff *, Eric Bachli, Molly Lansdowne and Theodora Capaldo \\ New England Anti-Vivisection Society, 333 Washington St. Suite 850, Boston, MA 02108, USA; \\ E-Mails: etbachli@gmail.com (E.B.); mlansdowne@neavs.org (M.L.); \\ theodoracapaldo@neavs.org (T.C.)
}

* Author to whom correspondence should be addressed; E-Mail: katherinegroff@gmail.com; Tel.: +1-617-523-6020; Fax: +1-617-523-7925.

Received: 13 March 2014; in revised form: 26 May 2014 / Accepted: 28 May 2014 /

Published: 6 June 2014

\begin{abstract}
Millions of animals are used in research and toxicity testing, including in drug, medical device, chemical, cosmetic, personal care, household, and other product sectors, but the environmental consequences are yet to be adequately addressed. Evidence suggests that their use and disposal, and the associated use of chemicals and supplies, contribute to pollution as well as adverse impacts on biodiversity and public health. The objective of this review is to examine such evidence. The review includes examinations of (1) resources used in animal research; (2) waste production in laboratories; (3) sources of pollution; (4) impacts on laboratory workers' health; and (5) biodiversity impacts. The clear conclusion from the review is that the environmental implications of animal testing must be acknowledged, reported, and taken into account as another factor in addition to ethical and scientific reasons weighing heavily in favor of moving away from allowing and requiring animal use in research and testing.
\end{abstract}

Keywords: animal research; animal testing; adverse environmental impacts; laboratory waste production; breeding; laboratory health effects

\section{Introduction}

Millions of animals are bred, used, and ultimately disposed of potentially as pathogenic (i.e., capable of causing disease, such as bacteria, fungi, and protozoa) or hazardous waste, in research and 
toxicity testing, including in drug, medical device, chemical, cosmetic, personal care, household, and other product sectors. As with other large-scale uses of animals such as the farm animal industry, which rears and slaughters more than 50 billion land animals every year [1,2], this large number of animals used and disposed of in research and testing, and the associated use of chemicals and supplies, raises serious concerns about the overall environmental impact of using animals in this capacity. Estimates for global annual use in research and testing are variable, with the most comprehensive estimates ranging from 115.3 million to 126.9 million non-human vertebrate animals. Both estimates are considered conservative $[3,4]$. The U.S. uses the most animals in research and testing in the world [3]. In 2012, facilities in the U.S. reported to the United States Department of Agriculture (USDA) Animal and Plant Health Inspection Service (APHIS), the government agency responsible for regulating the use of animals in research and testing, that they used more than 875,000 animals in research and testing and held an additional 143,400 animals for breeding or future use (Numbers calculated from facility annual reports available at [5]).

Research facilities, however, do not report the number of cold-blooded animals, farmed animals used in agricultural research, or rats, mice, and birds bred and used for research. Together, these species, while unreported, constitute the vast majority of animals (an estimated 95\%) used in research [6-9]. A 2000 USDA survey estimated that 31-156 million animals (species required to be reported as well as those excluded) were actually used in the U.S. [3,10]. Further, the use of animals is believed to have increased since this survey was done due to the increased use of genetically modified (GM) animals and the introduction of large-scale chemical testing programs [4,11]. A 2004 report estimated that the number of mice alone used annually in U.S. laboratories is 100 million due to the significant growth in use of GM mice [10].

The number of animals used in research and testing is believed to be growing due in part to the development of GM mice. The creation of GM mice has inherent scientific flaws which lead to significant waste in the form of animals bred which are not actually used in research or testing, and instead become waste or unusable industrial by-products. For example, the majority of mice progeny may not have the trait or deformity the researchers desire, have unintended deformities, or have the planned deformity but are still determined to not be useful for the intended purpose. As a consequence, these animals are killed and their bodies disposed of into the environment in one form or another [11,12]. The number of animals euthanized in the production of GM models is not required for reporting purposes and, thus, not publicly available, making it difficult to quantify the volume of surplus animals destroyed [13]. The loss of life and waste generated is staggering due to the requirements of developing and maintaining a GM mouse. In one report, a medical school euthanized 33,348 of their 55,435 laboratory mice as surplus, and another facility in the United Kingdom "screened 26,000 mice and recovered 500 usable 'mutants" [11]. Given this, an enormous number of animals must have been used to develop the thousands of different mouse strains in the U.S.

According to the U.S. National Institutes of Health Office of Laboratory Animal Welfare (OLAW), "A research animal facility generates a significant amount of waste that must be removed and disposed of on a regular, frequent basis" [14]. This waste and resulting environmental consequences have not been adequately addressed. At a fundamental level, records regarding the total number of animals used in research are not reported to or required by the USDA, making an environmental analysis difficult. However, it is clear that a staggering number of animals are used and discarded, or simply 
discarded without being used because they are determined to be excess or develop a laboratory-acquired disease not being studied. This fact compels the need for an environmental analysis of the biomedical, cosmetic, and product industries' animal use.

While there are few specific studies on the environmental consequences of animal use in research, evidence demonstrates that their use and disposal, and the associated use of chemicals and supplies, contribute to pollution as well as adverse impacts on biodiversity and public health. The objective of this review is to examine such evidence. The review includes examinations of (1) resources used in animal research; (2) waste production in laboratories; (3) sources of pollution; (4) impacts on laboratory workers' health; and (5) biodiversity impacts. Awareness of these environmental impacts is necessary to fully examine the use of animals in research and testing, especially given the lack of regulatory mandate to fully account for all animals used in research and testing and to employ non-animal testing methods whenever available.

\section{Resources Used in Animal Research}

\subsection{Animals}

As described, millions of animals are used in research and testing, but because the Animal Welfare Act does not cover the vast majority of animals used, total numbers are not reported to the USDA. Here, to get an idea of the scale of animal and resource use, we examine their use in toxicity testing. Toxicity tests are conducted on animals in an attempt to demonstrate the safety and efficacy of drugs and certain chemicals. A standard series of toxicity tests may use upwards of 6000 to 12,000 animals and take years to complete $[15,16]$. To put this in perspective, while there were approximately 82,000 chemicals in commerce in 2005 and 700 new chemicals introduced each year [17], it took 30 years and $\$ 2$ billion to screen 300 chemicals using traditional animal toxicity tests [18]. In contrast, as part of the Environmental Protection Agency's new ToxCast program it took about five years to test 300 chemicals using 600 different rapid, automated in vitro tests with equal or greater predictive value [18]. Toxicity tests are often conducted in rats, mice, rabbits, or dogs, with at least three groups of animals receiving a test drug or chemical and another group serving as the control. The numbers of animals used varies depending on the type of test being conducted. For example, the number of animals per group ranges from 10 rats in 28-day toxicity studies to 20 rats per group in sub-chronic studies to 100 rats per group in combined chronic toxicity and carcinogenicity assays, which last for a minimum of two years. For developmental and reproductive studies, the litter is considered the experimental unit, and at least 20 litters per group are required. Animals used in toxicity tests may be held and dosed with chemicals or drugs for months or years [19].

As another example of the resource intensity of animal testing, compare two methods of carcinogenicity testing. In the in vivo (animal) method, carcinogenicity bioassays are conducted with rodents, typically rats and mice, for a minimum of 24 months (rats) and 18 months (mice) [19], and uses at least 400 animals [19]. In contrast, the U.S. National Cancer Institute (NCI) drug discovery and development arm (the Developmental Therapeutics Program (DTP)) has developed and implemented non-animal testing methods for carcinogenicity, anti-HIV drug efficacy, and certain categories of cell toxicity. For example, a panel of 60 human tumor cell lines (DTP Human Tumor Cell Line Screen) 
is used to identify compounds with anti-tumor effects. NCI developed these methodologies in the late 1980s because of its dissatisfaction with the poor predictability of animal testing in these areas - concluding that "persistence in the effort (to develop the methodologies) reflected dissatisfaction with the performance of prior in vivo primary screens" [20].

\subsection{Energy}

The quantity of energy consumed by research animal facilities is up to ten times more than offices on a square meter basis [21]. Animal research facilities require total fresh air exchanges for ventilation, using large volumes of air, resulting in a high consumption of energy and carbon emissions [21]. Increased energy utilization is observed as airflow exchange in a standard laboratory is up to 12 air exchanges per hour (ach), compared to an animal research facility that can be up to 20 ach [21]. Additional energy demands are due to the environmental and space needs of the animals, barrier protection from outside pathogens, indoor air quality, lighting, and the requirement for power intensive equipment in research [22]. Forty to fifty percent of energy consumed in the research animal facility is attributed to ventilation and an additional $10 \%-30 \%$ of energy consumed is used to chill air or water for cooling spaces and equipment [21].

\subsection{Chemicals}

A vast array of chemicals is involved in every step of animal research and testing, including chemicals for sanitation, disinfection, sterilization, animal care, and research and testing procedures. The Occupational Health and Safety Act (OSHA) helps protect laboratory workers by regulating the handling and disposal of hazardous chemicals, as well as other toxic, infectious, mutagenic, and carcinogenic agents [23]. However, OSHA is not responsible for alleviating the greater environmental impacts from the generation and disposal of these chemicals and agents.

Similar to other testing methods, animal research and testing involves the use of many toxic substances, including irritants, corrosive substances (e.g., bromine, sulfuric acid, hydrogen peroxide, chlorine, ammonia, chloramines, nitrogen dioxide, sodium hydroxide, phosphorus, phenol, nitric acid, sulfuric acid, hydrochloric acid, ammonia, phosphorus pentoxide, and calcium oxide), asphyxiants (e.g., acetylene, carbon dioxide, argon, helium, ethane, nitrogen, methane, carbon monoxide, hydrogen cyanide, and certain organic and inorganic cyanides), neurotoxins (e.g., mercury, organophosphate pesticides, carbon disulfide, xylene, tricholoroethylene, and $n$-hexane), reproductive and developmental toxins, and carcinogens. In addition, flammable, reactive, and explosive chemicals are used in such research [24]. Animal research laboratories also use a number of chemicals with unknown hazardous and carcinogenic properties. Animal testing may involve the use of these chemicals for longer time periods ([17], p. 40), in larger quantities ([17], p. 40), or for more functions than non-animal testing methods due to the length of some animal tests, numbers of animals that are used, or the use of chemicals for purposes extraneous to the research. Chemicals are used in laboratories with animals for testing, research, veterinary care, analgesia, anesthesia, euthanasia, and necropsy. The OLAW Institutional Animal Care and Use Committee (IACUC) Guidebook notes that due to these chemical uses, hazardous chemicals may be present in feed, feces, and urine ([14], p. 141). 
Finally, large amounts of chemicals also are used to maintain sanitized or sterile environments in laboratories with animals. For example, some facilities use chemical decontamination to kill infectious diseases such as hepatitis B or C after a study on animals [24]. According to OLAW's IACUC Guidebook:

In general, enclosures and accessories (e.g., cage tops) should be sanitized at least every two weeks. Solid bottom cages, water bottles and sipper tubes should usually be sanitized weekly. The supply lines of automatic watering systems should be flushed and disinfected on a regular basis ([14], p. 48).

This variety and frequency of chemical use is in addition to any chemicals actually being tested. Because many animal tests, such as chronic toxicity and carcinogenicity, are long-term studies, chemicals may be used for extensive lengths of time.

\section{Waste Production in Laboratories}

Millions of animal bodies, many of which are contaminated with toxic or hazardous chemicals, viruses, or infectious diseases, and significant amounts of other laboratory waste such as animal excrement, bedding, excess feed, caging, needles, syringes, and gavages, are discarded after use in research and testing every year.

The animal research industry also regularly and routinely must dispose of large amounts of hazardous wastes. Similar to incineration in other industries, animal research facilities emit many harmful substances, including ignitable, corrosive, reactive, and toxic wastes, and air pollutants such as nitrogen dioxide, sulfur dioxide, particulate matter, and carbon monoxide (for examples, see [25]). In addition, among the dozens of hazardous chemical substances, such as mercury, methane, and cyanide, handled by these facilities are known carcinogens, including benzene, arsenic, and formaldehyde, and possible carcinogens, including lead, DDT, and chloroform.

Carcasses, as well as other laboratory waste, may not be hazardous or infectious due only to exposure of the animals to diseases and chemicals, but may contain a combination of chemical, radioactive, and/or biological hazards. For example, animal tissue that contains a radioactively labeled toxic chemical is sometimes produced in toxicological studies. The most "prominent" laboratory waste created that is both chemically and biologically hazardous is animal carcasses and tissues that contain a toxic chemical. Examples include specimens preserved in formalin or ethanol and rodents that have been fed lead, PCBs, mercury, or other chemicals in toxicity studies. Wastes that are chemically and biologically hazardous are difficult to dispose of and few waste facilities can handle them [24].

Disposal methods for these biological wastes raise additional environmental concerns. Carcass disposal methods include rendering, landfill disposal, and incineration [26]. Incineration is the preferred method for managing radioactive animal carcasses and tissue [24], the method recommended by OLAW for disposal of contaminated feed and bedding [14], and the most common disposal method for U.S. laboratories [24]. Many facilities maintain incinerators on their property, while other facilities contract with commercial disposal companies [26]. 


\section{Sources of Pollution}

\subsection{Air Pollution}

Air pollution is produced by the emission of gases and particulates resulting from incineration of animal carcasses and laboratory supplies such as animal bedding that may contain experimental chemicals, drugs, and other toxins. The resulting release of toxic substances is due to processes common to all industries as well as to toxins specifically produced by incineration of animal carcasses. Incineration is an environmental concern due to fuel consumption to maintain required temperatures, the disposal of ash from incineration in landfills, and resultant air pollution.

Environmental groups have concluded that incineration is not environmentally sound [27,28]. Incineration is known to release toxic wastes containing dioxin, mercury, lead, and other harmful substances into the air as waste is burned, to emit particle pollution, to produce toxic ashes, and to contaminate local soil and vegetation [27,29,30].

Although for this review it was not possible to determine the percentage of incinerated waste from animal research and testing versus other industries, and the percentage may be smaller than other industries, it is important to address the fact that animal research and testing contributes to the negative environmental effects of incineration. In addition, according to the National Research Council (NRC) Committee on Health Effects of Waste Incineration:

Although emissions from incineration facilities can be smaller than emissions from other types of sources, it is important to assess incinerator emissions in the context of the total ambient concentration of pollutants in an area. In areas where the ambient concentrations are already close to or above environmental guidelines or standards, even relatively small increments can be important [31].

Incineration is extremely adverse to human health. A study in Taiwan demonstrated that stack gases from animal carcass incinerators contain higher concentrations of toxic heavy metals than standard medical waste incinerators, including iron, copper, zinc, lead, nickel, and manganese [32]. When a carcass which has accumulated heavy metals from research or testing is incinerated, the metals gather in the bottom ash in the incinerator, release into the atmosphere, or collect in the pollution control devices [32]. Polycyclic aromatic hydrocarbons (PAH) are also emitted in animal incinerator stack gases, with one study reporting the concentrations of the most carcinogenic PAH compounds to be 4.6-7.6 times greater than in standard medical waste incinerators [33]. PAHs are toxic, and epidemiological studies have shown PAHs to be carcinogenic [34]. They are persistent in the environment, and the most common way humans are exposed to them is by breathing contaminated air [35]. Incineration of animal carcasses also has been associated with ash barium levels exceeding accepted standards [26]. The EPA states that barium can "potentially cause gastrointestinal disturbances and muscular weakness resulting from acute exposures" and "has the potential to cause hypertension resulting from long-term exposures" [36].

People living in communities near incinerators of all types are potentially exposed to chemicals through the air or contact with the soil. Epidemiological studies have shown the health hazards, including bronchitis and decreased life expectancy, posed by exposure to air contaminated by incinerator 
waste [29]. Some pollutants, such as dioxins, furans, and mercury, are "persistent" chemicals that can be carried long distances in air, land, and water and affect distant areas from the incinerator [31]. According to the NRC Committee, "Pollutants emitted by incinerators that appear to have the potential to cause the largest health effects are particulate matter, lead, mercury, and dioxins and furans" [31]. In addition, toxins such as mercury are known to have the ability to cause significant neurological damage and birth defects, resulting in developmental delays and cognitive defects [27].

In addition to global warming pollutants, incineration releases gases, such as sulfur dioxide, carbon monoxide, and nitrogen oxide, that can cause or exacerbate respiratory and cardiovascular diseases such as asthma, bronchitis, heart attack, and stroke [29,37-39]. These emissions also decrease resistance to infections and, importantly, contribute to smog, acid rain, and ozone formation [40,41]. Exposure to airborne particulate matter is associated with increased risks for asthma, hypertension, stroke, and cardiac diseases [37,42], as well as increased mortality [42,43]. Incinerators of all types emit particulate matter into the atmosphere, which can increase the incidence of respiratory infection, reduce the volume of air inhaled, impair the lungs' ability to use that air, increase the risk of myocardial infarction, and increase the risk of other serious health problems [28,44]. A recent study found that 2.1 million deaths have been associated with fine particulate matter resulting from human activities [45].

\subsection{Water Pollution}

Soil contamination and runoff of animal waste and other debris related to drug and chemical testing may result in ground water contamination. Animal waste containing drugs and chemicals that may have unknown toxicities due to their experimental nature exacerbates the growing problem of drugs in public water supplies. A 2002 study by the U.S. Geological Survey found that $80 \%$ of sampled rivers and streams contained one or more pharmaceuticals [46], which could originate from the animal agriculture, medical, or research industries.

Public drinking water supplies are contaminated by animal testing because public water treatment facilities often cannot filter out drugs, hormones, and chemical solvents in wastewater (for references, see [47]). Similar to what occurs on a larger scale with pollutants in the animal agriculture industry, these potential toxins may then be carried in to surface water, groundwater tables, and public drinking water supplies [47,48]. There are related serious biological consequences for aquatic animals, and potentially serious health effects for humans, from the presence of antibiotics, endocrine disruptors, cytotoxic cancer drugs, and other drugs in lakes, rivers, streams, and drinking water [49,50]. For example, a 2006 study evaluated the effects of a mixture of drugs designed to mimic river and treated waste water content on human kidney cells, and found that cellular proliferation was reduced $10 \%-30 \%$ compared to control cells [51].

\subsection{Soil Contamination}

Incinerator residues and water runoff from animal testing facilities may result in soil contamination. Several studies have shown increased levels of heavy metals, dioxins, and polychlorinated dibenzofurans in the soil near incinerators [52-54]. The specific dioxin 2,3,7,8-TCDD, a byproduct of incomplete combustion, is an extremely toxic chemical, and according to International Agency for Research on 
Cancer (IARC) a definite human carcinogen [55]. Animal incinerator soil contaminants in bottom ash and fly ash also include calcium, phosphorus, and potassium, which can have toxic effects [56].

\section{Impacts on Laboratory Workers' Health}

\subsection{Laboratory Animal Allergy}

The environmental hazards associated with animal research have direct implications on human health. Animals in laboratories are often tightly packed in rooms without outdoor access and dependent on modern air filtration systems. Laboratory animal allergen exposure and the subsequent development of an allergic reaction and asthma remains an important occupational health and environmental safety risk for all personnel involved in the care and use of animals [57-63]. Laboratory animal allergy (LAA) has been formally recognized since 1989 as an occupational hazard by The National Institute for Occupational Safety and Health in the United States. In Great Britain, worker exposure to laboratory animals has been defined as one of the most common causal agents for occupational asthma [64] and has been documented by the Surveillance of Work-related and Occupational Respiratory Disease (SWORD) project since 1989.

Laboratory animal allergy is the collective term used to describe symptoms that may include allergic conjunctivitis, rhinitis, asthma, and dermatological reactions resulting from exposure to animal allergens. Most laboratory animal species have multiple allergen sources that are found in hair, dander, urine, saliva, and serum [65-68]. Inhalation of airborne allergen particles is the principle route of exposure with additional incidence resulting from direct skin and eye contact $[67,69]$. Percutaneous exposure from animal bites and needles contaminated with animal protein have been documented and may result in systemic allergic reactions such as anaphylaxis [70].

In the U.S., it is estimated that 40,000 to 125,000 individuals are exposed to laboratory animals [71]. The prevalence of work related allergic reactions ranges from $11 \%$ to $44 \%$ in exposed workers $[72,73]$. The prevalence of occupational asthma as a result of exposure to laboratory animal allergens ranges from 4 to $22 \%$ [72]. Comparatively, overall, about 2 million people work in environments in which they have constant contact with animals or animal products. Approximately $33 \%$ of these workers have allergic symptoms, and 10\% have symptoms of animal-induced asthma [67].

Laboratory animal workers who are in direct contact with animals are at greatest risk of developing LAA. Indirect exposure may also result through the transfer of animal allergens from the animal facility to the home or general public and has been linked to increased sensitization to animals among children whose parents are occupationally exposed to animals in laboratories [60,74].

Exposure to laboratory animal allergens is an environmental hazard and occupational safety concern that can be eliminated by replacing the current predominance of animal research and testing with in vitro alternatives.

\subsection{Waste Anesthetic Gases (WAGs)}

Waste anesthetic gases (WAGs) are gases and vapors that can leak into the breathing zone and environment of laboratory personnel during medical procedures. Inhalation of WAGs has been associated with both acute and long term chronic effects. Acute symptoms include drowsiness, headaches, 
irritability, depression, dizziness, nausea, and neurobehavioral effects. Increased incidences of neurologic and reproductive dysfunction, hepatic and renal toxicity, and neoplasia have been linked to chronic low-level exposure of health care professionals [75]. Nitrous oxide and halogenated anesthetics such as isoflurane are commonly used in animal research facilities and pose an unnecessary environmental health risk in the workplace. The occupational health hazard for personnel working with animals in laboratories is potentially elevated due to facilities performing anesthetic procedures in small, multi-user rooms; the presence of many different portable anesthetic gas delivery systems complicating routine maintenance, gas scavenging, and atmospheric monitoring; and prolonged exposure to WAGs during experimental procedures for large treatment groups [75]. The United States Occupational Safety and Health Administration does not have standards that specifically address waste anesthetic gases, however, the National Institute of Occupational Safety and Health has recommended that halogenated anesthetic exposure not exceed 2 parts per million (ppm) on a time weighted average. According to one study examining WAGs in laboratory animal facilities, intermittent staff exposure to isoflurane emissions at concentrations exceeding 5 to $10 \mathrm{ppm}$ is likely [75]. In many animal research laboratories, isoflurane is the preferred gas anesthetic [76].

\subsection{Laboratory Acquired Infections (LAI)}

Zoonotic disease transmission in an animal research facility is an occupational safety and health risk affecting laboratory animal handlers. Laboratory acquired infections (LAI) can occur through direct contact with the animals or indirect contact by means of contaminated tissue, equipment, and supplies. The primary mode of transmission is air borne through aerosolization of infectious material with additional exposure risks from animal bites, scratches, exposure to contaminated equipment, and accidental ingestion of contaminated material [77]. The American College of Laboratory Animal Medicine classifies macaques, pigs, dogs, rabbits, mice, and rats as the most common species used in research animal facilities that are established or potential hosts for zoonotic disease [78]. Ringworm, Q fever, cat scratch disease, ectoparasites, and simian foamy virus represent a small number of zoonotic diseases in which confirmed cases have been reported in recent years and it is speculated that overall disease incidence is underreported [79]. One study estimated the annualized incidence rate of zoonotic disease transmission from laboratory animals at 45 cases per 10,000 worker-years, a rate comparable to nonfatal occupational illnesses for full time workers in the agricultural production-livestock industry and for those employed in the health services industry [79].

In documented cases of zoonosis in animal research facilities the severity of LAI ranges from asymptomatic to death [79]. Case examples of LAIs in animal research facilities have been recently reported including a deadly outbreak of respiratory illness in a colony of titi monkeys at the California National Primate Research Center that was transmitted to a researcher in May 2009 [80]. The adenovirus responsible for the outbreak is a novel strain known as titi-monkey adenovirus (TMAdV) that resulted in 23 of 65 monkeys developing symptoms with an 83\% mortality rate [80]. A researcher at the facility who had close contact with the infected colony developed flu-like upper-respiratory-tract symptoms, including pneumonia, shortly thereafter and a family member of the researcher also acquired the illness; both recovered and tested positive for antibodies to TMAdV providing strong evidence of cross transmission from the monkeys to the researcher [81]. In more severe circumstances, death has 
occurred due to laboratory acquired infections in research animal facilities. In 1997 a primate researcher at Yerkes Regional Primate Research Center was infected with herpes B following exposure to a drop of body fluid from a rhesus monkey [82]. The researcher died six weeks following the exposure to herpes B, a virus common in primates but rare in humans. In humans, it has a $70 \%$ mortality rate [83].

\section{Biodiversity Impacts}

\subsection{Capture from the Wild}

We are in an era of unprecedented threats to biodiversity. The current loss of species is estimated to be 50 to 500 times higher than the natural background rates found in the fossil record [84]. Tens of thousands of monkeys have been captured from the wild and transported to research facilities in the U.S. and other countries over the past few years [85]. This alarming fact raises not only animal welfare concerns but also population and biodiversity concerns. Population data for many species of monkeys traded for research are lacking. According to Ardith Eudey of the World Conservation Union Primate Specialist Group, "Macaques (the most commonly used monkey in laboratories) frequently are considered as well known or common: as a consequence, data on the present status of populations such as numbers, distribution and population trends are deficient for most species, especially those that are widespread geographically..." [86].

In 2008 Eudey expressed concern that the long-tailed macaque (Macaca fascicularis), a species of monkey commonly used in animal research, population was rapidly declining in the wild [87]. Although most traded long-tailed macaques are reported as being captive bred, Eudey and non-governmental organizations suspect that the export of wild-caught monkeys continues, using false permits [86]. Thus, it is suspected that claims of captive breeding are hiding increased numbers of wild-caught monkeys. In addition, breeding farms continue to obtain long-tailed macaques from the wild [88].

The World Conservation Union Red List currently lists the international trade for laboratory research as a threat to the continued existence of the long-tailed and rhesus macaques $[87,89]$. Regarding the rhesus macaque, it states, "Confiscation for laboratory testing is a mostly localized threat, but it is considerable in certain areas... Capture and release of laboratory and "problem monkeys' from rural and urban areas into natural forests is a major threat to wild macaques" [89].

In 2012, 17,915 non-human primates were imported into the U.S. [85]. The vast majority, 15,110, were long-tailed macaques, also known as crab-eating macaques. More than 1000 rhesus macaques and green monkeys each were imported. $55.9 \%$ of the monkeys imported originated in China, $18.4 \%$ in Mauritius, $8 \%$ in Cambodia, $7.9 \%$ in Vietnam, $6.4 \%$ in Saint Kitts and Nevis, $1.3 \%$ in Indonesia, and $0.62 \%$ in Guyana. Research facilities are the largest importers of primates [85]. While Fish and Wildlife Service documents indicate that $7.8 \%$ of primates imported are wild-caught and $26.1 \%$ were born to parents who were wild-caught [85], there are reports of falsified documents indicating that the monkeys were captive-bred when in fact they were not.

Of further note, the trade in monkeys for research and testing raises concerns about the growth and spread of dangerous pathogens. Animals are exposed to conditions of over-crowding, extreme 
temperatures, and unsanitary conditions. In these conditions, animal diseases are common, resulting in "ideal conditions for pathogens to multiply" [90].

\subsection{Genetically Modified Animals}

The development and proliferation of GM animals in research facilities raises concerns as to the impact these animals could potentially have on the environment and indigenous populations if they are released or escape. In 2002 the National Academies' National Research Council expressed these concerns in a formal report requested by the Food and Drug Administration. In the report the committee concludes that the potential for GM animals escaping and interbreeding with or out-competing wild populations is the primary concern with advances in animal biotechnology [91]. This concern is further expressed in an article regarding the welfare of GM animals. The author states, "If animals whose genome has been altered by the stable introduction of recombinant DNA in the germ line should escape and breed with feral populations, the environment could be altered and a disastrous situation might be created" [92].

\section{Conclusions}

Record-keeping and regulation of all environmental aspects of animal research and testing are extremely limited or non-existent. At a fundamental level, rats, mice, and birds must be covered under the Animal Welfare Act in order to begin recording the scope of animal use. Although records and studies are limited, this review attempts to elucidate areas of environmental concern. Further areas of environmental concern necessary to address include:

- The use of animals, and associated chemicals and supplies, in research and testing, and their disposal in to the environment on an international level. Many animal research companies based in the U.S. have labs in other countries, including China, the Philippines, and India.

- Research and testing involving injecting or exposing animals to radioactive materials creates radioactive carcasses, feces, urine, blood, and other wastes with additional environmental concern. In addition, working with animals who have received radioactive material presents a risk to workers in labs.

- Large scale killing of animals used in research or bred for future research due to disease, facility resource constraints, funding limitations, and research demands are further examples of waste and animal disposal concerns found in the animal research industry.

While industries such as those involved in animal agriculture and energy production have a larger contribution to the negative environmental impacts discussed in this review, it is important to address the impacts of all industries and to discuss all methods to alleviate them. Animal research and testing uses more than 100 million animals every year, contributing to air, water, and soil pollution, public health concerns, and biodiversity concerns. In addition, there are a multitude of alternative testing methods.

Non-animal methods have the inherent advantage of sparing significant numbers of animals from the pain and distress commonly associated with laboratory life and use, a goal consistent with public opinion polls [93-95]. Additionally, non-animal methods are often less costly and less time-consuming 
to perform and promise faster delivery of test results with greater applicability to humans [17]. For all of these reasons, industry, government agencies, and other stakeholders must in due diligence consider the environmental impacts of animal testing and research in deciding whether to require the use of non-animal alternatives whenever available.

\section{Acknowledgments}

The authors would like to express their gratitude to Jarrod Bailey for his initial research regarding the environmental effects of air pollution, water pollution, and soil contamination. We also thank Mark Axelrod and Rick Borchelt for their reviews of and helpful comments on this manuscript.

\section{Author Contributions}

Katherine Groff designed the review, conducted research, and wrote the main manuscript. Eric Bachli conducted research and conceived of and wrote the sections of the review on the impacts on laboratory workers' health. Molly Lansdowne conducted research. Theodora Capaldo conceived of the review and contributed to the editing process. All authors discussed the results.

\section{Conflicts of Interest}

While preparing this manuscript, the authors were employed by NEAVS, whose mission is to end the use of animals in research, testing, and science education.

\section{References}

1. Koneswaran, G.; Nierenberg, D. Global farm animal production and global warming: Impacting and mitigating climate change. Environ. Health Perspect. 2008, 116, 578-582.

2. Food and Agriculture Organization of the United Nations, "FAOSTAT" 2012. Available online: http://faostat.fao.org/ (accessed on 22 May 2014).

3. Taylor, K.; Gordon, N.; Langley, G.; Higgins, W. Estimates for worldwide laboratory animal use in 2005. Altern. Lab. Anim. 2008, 36, 327-342.

4. Knight, A. The Costs and Benefits of Animal Experiments; Palgrave Macmillan: Basingstoke, UK, 2011.

5. USDA. Animal Care Information System Search Tool. Available online: http://acissearch.aphis.usda.gov/ LPASearch/faces/CustomerSearch.jspx. (accessed on 25 July 2013).

6. Cohen, H. The animal welfare act. J. Anim. Law 2006, 2, 13-26.

7. Animal Welfare Institute. Rats, Mice \& Birds. Available online: https://awionline.org/ content/rats-mice-birds (accessed on 10 May 2013).

8. California Biomedical Research Association. Why Are Animals Necessary in Biomedical Research? Available online: http://ca-biomed.org/csbr/pdf/fs-whynecessary.pdf (accessed on 10 May 2013).

9. Americans for Medical Progress. Animal Research FAQs: The Top 10 Questions. Available online: http://www.amprogress.org/AnimalResearchFAQ (accessed on 10 May 2013). 
10. Carbone, L. What Animals Want: Expertise and Advocacy in Laboratory Animal Welfare Policy; Oxford University Press: San Francisco, CA, USA, 2004.

11. Stallwood, A.; Aid, A.; Science Corrupted: Revealed: The Nightmare World of GM Mice; Tyler, A., Ed.; Animal Aid: Kent, UK, 2013.

12. Robinson, V.; Jennings, M.; Working Group. Refinement and reduction in the production of genetically modified mice: Sixth report of the BVAAWF/FRAME/RSPCA/UFAW Joint Working Group on Refinement. Altern. Lab. Anim. (ATLA) 2004, 32, 373-375.

13. Animal Welfare Act. 7 U.S.C. § 2131-2159; United States Congress: Washington, DC, USA, 1966.

14. Office of Laboratory Animal Welfare. Institutional Animal Care and Use Committee Guidebook; National Institutes of Health: Bethesda, MD, USA, 2002.

15. Bus, J. Current State and Directions of Animal Toxicity Testing. Presented at the American Chemical Society/Society of Toxicology/Society for Risk Analysis Congressional Briefing. Available online: http:/www.acs.org/content/dam/acsorg/policy/acsonthehill/briefings/toxicitytesting/ bus-presentation.pdf (accessed on 10 December 2009).

16. Sullivan, K.; Beck, N.; Sandusky, C.; Willett, C. A discussion of the impact of us chemical regulation legislation on the field of toxicity testing. Toxicol. In Vitro 2011, 25, 1231-1236.

17. National Research Council Committee on Toxicity and Assessment of Environmental Agents. Toxicity Testing in the Twenty-first Century: A Vision and a Strategy; National Academies Press: Atlanta, GA, USA, 2007.

18. EPA National Center for Computational Toxicology. Computational Toxicology Research Program. Available online: http://www.epa.gov/ncct/toxcast/ (accessed on 23 Sepember 2013).

19. National Research Council. Toxicity Testing for Assessment of Environmental Agents: Interim Report, 2006. Available online: http://www.nap.edu/openbook.php?record_id=11523\& displayrelated=1 (accessed on 25 July 2013).

20. Developmental Therapeutics Program. NCI-60 DTP Human Tumor Cell Line Screen. Available online: http://dtp.nci.nih.gov/branches/btb/ivclsp.html (accessed on 26 July 2013).

21. Cubitt, S.; Sharp, G. Maintaining quality and reducing energy in research animal facilities. Animal Technology and Welfare, August 2011, pp. 91-97.

22. Reynolds, S.D. Green and lean: Methods of improving lab animal room ventilation. ALN, 31 December 2008.

23. National Research Council Committee for the Update of the Guide for the Care and Use of Laboratory Animals. Guide for the Care and Use of Laboratory Animals, 8th ed.; National Academies Press: Washington, DC, USA, 2011.

24. National Research Council. Prudent Practices in the Laboratory: Handling and Management of Chemical Hazards. 2011. Available online: http://www.nap.edu/openbook.php?record_ id $=12654$ (accessed on 25 July 2013).

25. EPA. Envirofacts Multisystem Search. Available online: http://www.epa.gov/enviro/facts/ multisystem.html (accessed on 25 July 2013).

26. Suckow, M.A.; Douglas, F.A.; Weichbrod, R.H. Management of Laboratory Animal Care and Use Programs; CRC Press: Boca Raton, FL, USA, 2002. 
27. Union of Concerned Scientists. Comments of the Union of Concerned Scientists before the Maine Legislature's Utilities and Commerce Committee on LD 1312: The Maine Renewable Resource Portfolio Requirement. 9 April 2003. Available online http://www.ucsusa.org/assets/documents/ clean_energy/me-comments-4-9-03.pdf (accessed on 25 July 2013).

28. Allsopp, M.; Costner, P.; Johnston, P. Incineration and human health. Environ. Sci. Pollut. Res. 2001, 8, 141-145.

29. Franchini, M.; Rial, M.; Buiatti, E.; Bianchi, F. Health effects of exposure to waste incinerator emissions:a review of epidemiological studies. Ann. DellIstituto Super. Sanità. 2004, 40, 101-115.

30. EPA. Boilers, Process Heaters, Commercial/Industrial Solid Waste Incinerators. Available online: http://www.epa.gov/airquality/combustion/ (accessed on 27 Febuary 2014).

31. National Research Council Committee on Health Effects of Waste Incineration. Waste Incineration and Public Health; The National Academies Press: Washington, DC, USA, 2000.

32. Chen, S.-J.; Hung, M.-C.; Huang, K.-L.; Hwang, W.-I. Emission of heavy metals from animal carcass incinerators in Taiwan. Chemosphere 2004, 55, 1197-1205.

33. Chen, S.-J.; Hsieh, L.-T.; Chiu, S.-C. Emission of polycyclic aromatic hydrocarbons from animal carcass incinerators. Sci. Total Environ. 2003, 313, 61-76.

34. WHO Regional Office for Europe. Air Quality Guidelines, 2nd ed.; WHO Regional Office for Europe: Copenhagen, Denmark, 2000.

35. EPA. Polycyclic Aromatic Hydrocarbons. Jan-2008. Available online: http://www.epa.gov/ osw/hazard/wastemin/minimize/factshts/pahs.pdf (accessed on 25 July 2013).

36. EPA. Technical Factsheet on: Barium. Available online: http://www.epa.gov/ogwdw/pdfs/ factsheets/ioc/tech/barium.pdf (accessed on 25 July 2013).

37. D’Amato, G.; Liccardi, G.; D'Amato, M.; Holgate, S. Environmental risk factors and allergic bronchial asthma. Clin. Exp. Allergy 2005, 35, 1113-1124.

38. Bernstein, J.A.; Alexis, N.; Barnes, C.; Bernstein, I.L.; Bernstein, J.A.; Nel, A.; Peden, D.; Diaz-Sanchez, D.; Tarlo, S.M.; Williams, P.B. Health effects of air pollution. J. Allergy Clin. Immunol. 2004, 114, 1116-1123.

39. Maynard, R. Key airborne pollutants-The impact on health. Sci. Total Environ. 2004, 334-335, 9-13.

40. National Geographic. Air Pollution. Available online: http://environment.nationalgeographic.com/ environment/global-warming/pollution-overview/ (accessed on 25 July 2013).

41. Rowat, S.C. Incinerator toxic emissions: A brief summary of human health effects with a note on regulatory control. Med. Hypotheses 1999, 52, 389-396.

42. Brook, R. You are what you breathe: Evidence linking air pollution and blood pressure. Curr. Hypertens. Rep. 2005, 7, 427-434.

43. Krewski, D.; Burnett, R.; Goldberg, M.; Hoover, K.; Siemiatycki, J.; Jerrett, M.; Abrahamowicz, M.; White, W. Overview of the reanalysis of the Harvard six cities study and American Cancer Society study of particulate air pollution and mortality. J. Toxicol. Environ. Health A 2003, 66, 1507-1552.

44. EPA. Extramural Research: Particulate Matter. Available online: http://www.epa.gov/ncer/ science/pm/ (accessed on 17 January 2014). 
45. Silva, R.A.; West, J.J.; Zhang, Y.; Anenberg, S.C.; Lamarque, J.-F.; Shindell, D.T.; Collins, W.J.; Dalsoren, S.; Faluvegi, G.; Folberth, G.; et al. Global premature mortality due to anthropogenic outdoor air pollution and the contribution of past climate change. Environ. Res. Lett. 2013, 8, doi: 10.1088/1748-9326/8/3/034005.

46. United States Geological Survey. Pharmaceuticals, hormones, and other organic wastewater contaminants in US streams. Environ. Sci. Technol. 2002, 36, 1202-1211.

47. Stackelberg, P.E.; Furlong, E.T.; Meyer, M.T.; Zaugg, S.D.; Henderson, A.K.; Reissman, D.B. Persistence of pharmaceutical compounds and other organic wastewater contaminants in a conventional drinking-water-treatment plant. Sci. Total Environ. 2004, 329, 99-113.

48. Kolpin, D.; Furlong, E.; Meyer, M.; Thurman, E.M.; Zaugg, S.; Barber, L.; Buxton, H. Pharmaceuticals, hormones, and other organic wastewater contaminants in U.S. streams, 1999-2000: A national reconnaissance. Environ. Sci. Technol. 2002, 36, 1202-1211.

49. Pill-popping society fouling our water. $C B C$ News, 27 March 2006.

50. Daughton, C.G.; Ternes, T.A. Pharmaceuticals and personal care products in the environment: Agents of subtle change? Environ. Health Perspect. 1999, 107, 907-938.

51. Pomati, F.; Castiglioni, S.; Zuccato, E.; Fanelli, R.; Vigetti, D.; Rossetti, C.; Calamari, D. Effects of a complex mixture of therapeutic drugs at environmental levels on human embryonic cells. Environ. Sci. Technol. 2006, 40, 2442-2447.

52. Segura-Muñoz, S.I.; Takayanagui, A.M.M.; Trevilato, T.M.B.; Santos, C.B.; Hering, S.E. Trace metal distribution in surface soil in the area of a municipal solid waste landfill and a medical waste incinerator. Bull. Environ. Contam. Toxicol. 2004, 72, 157-164.

53. Jimenez, B.; Eljarrat, E.; Hernández, L.M.; Rivera, J.; Gonzálezl, M.J. Polychlorinated dibenzo-p-dioxins and dibenzofurans in soils near a clinical waste incinerator in Madrid, Spain. Chemometric comparison with other pollution sources and soils. Chemosphere 1996, 32, 1327-1348.

54. Oh, J.-E.; Choi, S.-D.; Lee, S.-J.; Chang, Y.-S. Influence of a municipal solid waste incinerator on ambient air and soil PCDD/Fs levels. Chemosphere 2006, 64, 579-587.

55. Mandal, P.K. Dioxin: A review of its environmental effects and its aryl hydrocarbon receptor biology. J. Comp. Physiol. 2005, 175, 221-230.

56. Thompson, L.J.; Ebel, J.G., Jr.; Manzell, K.L.; Rutzke, M.; Gutenmann, W.H.; Lisk, D.J. Analytical survey of elements in veterinary college incinerator ashes. Chemosphere 1995, 30, $807-811$.

57. The National Institute for Occupational Safety and Health. Preventing asthma in animal handlers. NIOSH Alert, 1998. Available online: http://www.cdc.gov/niosh/docs/97-116/pdfs/97-116sum.pdf (accessed on 9 May 2014).

58. Stave G.M.; Darcey, D.J. Prevention of laboratory animal allergy in the United States: A national survey. J. Occup. 2012, 54, 558-563.

59. Pacheco, K.A.; McCAMMON, C.; Thorne, P.S.; O’neill, M.E.; Liu, A.H.; Martyny, J.W.; Vandyke, M.; Newman, L.S.; Rose, C.S. Characterization of endotoxin and mouse allergen exposures in mouse facilities and research laboratories. Ann. Occup. Hyg. 2006, 50, 563-572, 
60. Krop, E.J.M.; Doekes, G.; Stone, M.J.; Aalberse, R.C.; van der Zee, J.S. Spreading of occupational allergens: Laboratory animal allergens on hair-covering caps and in mattress dust of laboratory animal workers. Occup. Environ. Med. 2007, 64, 267-272.

61. Nicholson, P.J.; Mayho, G.V.; Roomes, D.; Swann, A.B.; Blackburn, B.S. Health surveillance of workers exposed to laboratory animal allergens. Occup. Med. 2010, 60, 591-597.

62. Elliott, L.; Heederik, D.; Marshall, S.; Peden, D.; Loomis, D. Incidence of allergy and allergy symptoms among workers exposed to laboratory animals. Occup. Environ. Med. 2005, 62, 766-771.

63. Gordon, S.; Preece, R. Prevention of laboratory animal allergy. Occup. Med. 2003, 53, 371-377.

64. Health and Safety Executive. Occupational Asthma in Great Britain 2013. Available online: http://www.hse.gov.uk/statistics/causdis/asthma/asthma.pdf (accessed on 10 December 2013).

65. Bush, R.K.; Wood, R.A.; Eggleston, P.A. Laboratory animal allergy. J. Allergy Clin. Immunol. 1998, 102, 99-112.

66. National Institutes of Health Division of Occupational Health and Safety. The National Institutes of Health Laboratory Animal Allergy Prevention Program. 5 Febuary 2014. Available online: http://www.ors.od.nih.gov/sr/dohs/Documents/LAAPP.pdf (accessed on 9 May 2014).

67. CDC-NIOSH Publications and Products_-Preventing Asthma in Animal Handlers (97-116). Available online: http://www.cdc.gov/niosh/docs/97-116/ (accessed on 9 May 2014).

68. Glueck, J.T.; Huneke, R.B.; Perez, H.; Burstyn, I. Exposure of laboratory animal care workers to airborne mouse and rat allergens. J. Am. Assoc. Lab. Anim. Sci. JAALAS 2012, 51, 554-560.

69. Harrison, D.J. Controlling exposure to laboratory animal allergens. ILAR J. 2001, 42, 17-36.

70. Bush R.K.; Stave, G.M. Laboratory animal allergy: An update. ILAR J. Natl. Res. Counc. Inst. Lab. Anim. Resour.2003, 44, 28-51.

71. Seward, J.P. Occupational allergy to animals. Occup. Med. Phila. Pa 1999, 14, 285-304.

72. Seward, J.P. Medical surveillance of allergy in laboratory animal handlers. ILAR J. Natl. Res. Counc. Inst. Lab. Anim. Resour. 2001, 42, 47-54.

73. Jones, M.; Schofield, S.; Jeal, H.; Cullinan, P. Respiratory protective equipment reduces occurrence of sensitization to laboratory animals. Occup. Med. 2014, 64, 104-108.

74. Krakowiak, A.; Szulc, B.; Górski, P. Allergy to laboratory animals in children of parents occupationally exposed to mice, rats and hamsters. Eur. Respir. J. 1999, 14, 352-356.

75. Smith, J.C.; Bolon, B. Atmospheric waste isoflurane concentrations using conventional equipment and rat anesthesia protocols. Contemp. Top. Lab. Anim. Sci. Am. Assoc. Lab. Anim. Sci. 2002, 41, $10-17$.

76. Taylor, D.K.; Mook, D.M. Isoflurane waste anesthetic gas concentrations associated with the open-drop method. J. Am. Assoc. Lab. Anim. Sci. JAALAS 2009, 48, 61-64.

77. Fox, J.G.; Anderson, L.C.; Loew, F.M.; Quimby, F.W. Laboratory Animal Medicine; Academic Press: Waltham, MA, USA, 2002.

78. Hankenson, F.C.; Johnston, N.A.; Weigler, B.J.; Di Giacomo, R.F. Zoonoses of occupational health importance in contemporary laboratory animal research. Comp. Med. 2003, 53, 579-601.

79. Weigler, B.J.; Di Giacomo, R.F.; Alexander, S. A national survey of laboratory animal workers concerning occupational risks for zoonotic diseases. Comp. Med. 2005, 55, 183-191. 
80. Cormier, Z. Respiratory virus jumps from monkeys to humans. Nat. News 2011, doi:10.1038/news.2011.416.

81. Yu, G.; Yagi, S.; Carrion, R., Jr.; Chen, E.C.; Liu, M.; Brasky, K.M.; Lanford, R.E.; Kelly, K.R.; Bales, K.L.; Schnurr, D.P.; et al. Experimental cross-species infection of common marmosets by titi monkey adenovirus. PloS One 2013, 8, doi:10.1371/journal.pone.0068558.

82. Mullen, W. Monkeys can pose threat. Chicago Tribune, 13 December 1997.

83. Bragg, R. A drop of virus from a monkey kills a researcher in 6 weeks. New York Times, 14 December 1997.

84. Food and Agriculture Organization of the United Nations. Livestock's Long Shadow: Environmental Issues and Options; FAO: Roma, Italy, 2006.

85. Strong, S. U.S. primate import statistics for 2012. Int. Primat. Trade 18 January 2013.

86. Eudey, A.A. The Crab-Eating Macaque (Macaca fascicularis): Widespread and rapidly declining Primate. Conserv. 2008, 23, 129-132.

87. Ong P.; Richardson, M. IUCN Red List of Threatened Species: Macaca fascicularis Version 2013.2, 2008. Available online: http://www.iucnredlist.org (accessed on 23 May 2014).

88. Nadler, T.; Thanh, V.; Streicher, U. Conservation status of Vietnamese primates. Vietnam. J. Primatol. 2007, 1, 7-26.

89. Timmins, R.; Richardson, M.; Changani, A.; Yongcheng, L. IUCN Red List of Threatened Species: Macaca mulatta. 2008. Available online: http:/Www.iucnredlist.org (accessed on 23 May 2014).

90. Akhtar, A. The need to include animal protection in public health policies. J. Public Health Policy 2013, 34, 549-559.

91. National Research Council. Animal Biotechnology: Science Based Concerns; The National Academies Press: Washington, DC, USA, 2002.

92. Dennis, M.B. Welfare issues of genetically modified animals. ILAR J. 2002, 43, 100-109.

93. Gallup Poll. Older Americans' Moral Attitudes Changing. Available online: http://www.gallup.com/ poll/162881/older-americans-moral-attitudes-changing.aspx?version=print (accessed on 20 December 2013).

94. Humane Research Council. The Animal Tracker. Available online: http://spot.humaneresearch.org/ content/animal-tracker-wave-4-march-2011 (accessed on 26 February 2014).

95. Lake Research Partners. Ending Cosmetic Testing on Animals in the United States. Available online: http://www.humanesociety.org/assets/pdfs/animals_laboratories/cosmetic_product_testing/ cosmetic_testing_poll_results.pdf(accessed on 15 January 2014).

(C) 2014 by the authors; licensee MDPI, Basel, Switzerland. This article is an open access article distributed under the terms and conditions of the Creative Commons Attribution license (http://creativecommons.org/licenses/by/3.0/). 